\title{
Competititive intelligence and competitivenes
}

\author{
Marié-Luce Muller \\ Managing Director and CI Analyst \\ IBIS Business and Information Services \\ mlm@ibis.co.za \\ www.ibis.co.za
}

With the recent World Economic Forum (WEF) held in Cape Town, South Africa, from 4 to 6 June 2008, Africa and South Africa's competitiveness once again fell under the spotlight. The latest WEF Global Competitiveness Report (2008) mentions that African businesses can become more competitive but that African governments, in partnership with global players, should provide the right support in the form of improved access to finance, improved infrastructure and better institutional capacity. In turn, corporates could, in partnership with governments, NGOs and bodies like the UN and World Bank, provide more focused corporate citizenship.

The World Competitiveness Scoreboard, released in May 2008 by the Swiss International Business School IMD, too, highlighted some strides of improvement in terms of South Africa's global competitiveness ranking. Overall, however, South Africa's ranking slipped once more, this time from 50th to 53rd position (IMD 2008). The World Competitiveness Scoreboard ranks 55 economies from the most to the least competitive.

In the Global Competitiveness Index rankings (WEF 2008), South Africa also fell three places to 44th from 41 (in 2007) and 36th in 2006. In Africa, Tunisia consistently performs best in Africa in terms of rankings with both the IMD and the WEF. In the Global Competitiveness Index (GCI) rankings (WEF 2008), Tunisia achieved 32nd place, the same ranking as in 2007 and one better than in 2006 when it achieved 33rd place. What is interesting and important to note regarding Tunisia, is that it maintains its ranking.

Although there has been significant growth in Africa's gross domestic product (GDP) over the past number of years (World Bank 2007), most of the current growth of 6,2\% is achieved by factors such as high commodity prices, debt relief, and a favourable international economic environment. This however does not guarantee sustainable growth. This requires certain factors to be in place.

The Africa Competitiveness Report (2007) and the WEF's GCI mention a number of factors or pillars for competitiveness that need to be in place to achieve sustainable competitiveness. These factors are interdependent and reinforce one another.

1. Sound policies: Countries that have implemented sound policies rank higher on competitiveness, with better growth and productivity outcomes. An institutional environment forms the framework within which individuals, companies and governments interact to generate income and wealth and efficiency

2. Access to finance and an efficient financial sector

3. Infrastructure is critical for ensuring efficient functioning of the economy in terms of transport, telecommunications and power

4. Good governance to prevent corruption from undermining competitiveness 
5. Quality education and technological readiness

6. Stable macro-economic environment

7. A healthy appropriately skilled workforce

8. A large and efficient goods markets enabling business to achieve economies of scale

9. An agile economy that adopts emerging technologies which in turn could enhance the productivity of industries

10. Sophisticated and efficient businesses

11. Culture of innovation that in turn created knowledge

The question then begs what businesses and governments can do to enhance competitiveness. In an interview at the World Economic Forum in Cape Town on 5 June 2008, E. Neville Isdell, CEO of The Coca-Cola Company (Engineering News 2008) said that there are a number of positive, competitive indicators in Africa and these can be used to build competitiveness on the continent. He mentioned that Africa is benefiting from the global commodities boom and that it is time that these benefits filter through to the broader African societies.

Obliageli Ezekwesili, the World Bank's Vice President for African Region, said that the World Bank identified infrastructure, investment, innovation and institutional capacity as the most critical areas to redress should Africa wish to be part of the global competitiveness race (Ezekwesili 2008).

\section{Improved access to finance}

African businesses could become far more competitive if African governments and their international partners improve the continent's access to finance and infrastructure and strengthen Africa's institutions (Africa Competitiveness Report, 2007). According to the Report, lack of access to finance has even worse consequences for low-income countries, small business and businesses that lack an international presence. It is imperative that businesses grow. This leads to higher employment, better skills, higher productivity and ultimately to competitiveness. Good and efficient businesses will attract and retain the right talent. Governments, however, have a role to play in that they should create a regulatory environment that could simplify financing, create global market opportunities and create a secure business environment.

According to Aliko Dangote, President and Chief Executive Officer, Dangote Group, Nigeria; Co-Chair, WEF (WEF 2008), African companies are not competitive in investing abroad and have become stuck in activities related to primary raw materials and agricultural products. He concurs that one of the largest impediments is their low equity base, which limits their access to capital. Other factors that are a challenge to African businesses in terms of competitiveness are unsophisticated domestic financial markets, a lack of investment in Research and Development capacity and the bias they face in their own countries.

\section{Improved infrastructure}

Infrastructure remains one of the main constraints to business in Africa. This includes energy and transportation, which have been shown to be the main challenges to competitiveness in Africa. The continued power insecurity in South Africa is also a deterrent to foreign direct investment. Research has shown that companies lose as much as $8 \%$ of sales to power outages. Transportation impediments could lead to losses in sales of up to 3\% (Engineering News 2007). Besides power and transportation, an information and communication technologies (ICT) infrastructure also plays a vital role. ICT enables fast and efficient communication across and within countries. This is a critical success factor in the present global economy. 
Competitive countries have a solid telecommunications infrastructure. A secure national ICT network is one of the most important factors that can assist in strengthening the economy and improving the country's global competitiveness. Factors such as increased access and reduced cost are most important and requires a governing body to facilitate the process. Although, recently, South Africa has attracted many foreign investors, the country still needs to ensure that knowledge and technology are translated into higher production and efficiency. This would start with ensuring quality training and education in ICT and developing practical skills. According to a report in the Computer Business Review (2006), governments and corporations will then be able to take advantage of new technologies to improve business efficiencies, provide competitor advantage and maximize customer satisfaction.

\section{Enhanced institutional capacity}

As mentioned earlier, good government policies are necessary to establish and grow a sound business environment. Although some African countries have potential competitive edges, for example being closer to global markets or having richer resources, businesses in those countries do not regard them as having a business climate that is better than countries that have worse geographical proximities or have fewer resources.

One of the biggest challenges to competitiveness in Africa is corruption. The WEF describes corruption as manifesting in various ways including bribes and political favours being directed to special interest groups. Good governance means efforts are taken to combat corruption and promote a clear, rules-based legal system (WEF 2008). Indeed, a Commonwealth Business Environment Survey ranked corruption, policy instability and inadequate infrastructure as the biggest impediments to competitiveness in Africa (eAfrica 2004).

Isdell (2008) says that although there are a number of positive, competitive indicators in Africa, businesses need good governance to flourish and that governance should include the promotion of free market principles.

Africa's leadership is not doing enough to tackle crime and restore investor confidence. Wendy Luhabe (WEF 2008) argues that most of Africa's challenges are a result of poor leadership. A good business environment extends further into an efficient, modern, evolving educational system which in turn forms the basis for a good business environment, feeding the latter with the right skills and enhancing productivity. Skills and the right environment will then also lead to more value-add products.

Encouragingly, the South African government recognizes the importance of investing in educational and research and development programmes in order to build a knowledge economy. The South African Minister of Science and Technology, Mosibudi Mangena, in the Budget Vote debate 2008/2009, said that government's purpose is to build a knowledgebased economy in which the production and dissemination of knowledge leads to economic benefits (Mangena 2008). To remain competitive, South Africa needs to research how to enhance the quality and quantity of what the country produces. South African also needs to aim to attract and retain more talented recruits to the sciences.

\section{Corporate citizenship}

Corporate global citizenship grows in importance, and corporations should exercise their civic duty with regard to major global issues like the environment. According to Isdell, the Coca-Cola system contributes to economic growth and job creation throughout the African continent. As a local company in every country where its products are sold, it uses local inputs and local distribution systems (WEF 2008). 
According to Isdell (WEF 2008) corporations must enter into partnerships with governments and civil society on issues where it is appropriate and relevant for business to play a role. Such partnerships are key to accelerating sustainable development across Africa and globally. The Coca-Cola Company assists local communities in overcoming water challenges they are facing. This is especially true because water is fundamental to Coca-Cola's business and to the sustainability of the communities in which it operates. Equally, corporations can play a role in food security. These include support to the UN World Food Program, policies that promote increased agriculture production from existing arable land and revised trade subsidies

Luhabe (WEF 2008) said that corporates could establish funds in the countries where they operate, which can be invested in health, food and education provision of local communities.

\section{References}

Africa Competitiveness Report, 2007. World Economic Forum. [Online]. Available WWW: www.weforum.org (Accessed 9 June 2008).

\section{eAfrica. 2004. Impediments to competitiveness, Volume 2. (February).}

Engineering News. 2007. Infrastructure, finance hinder Africa's global competitiveness, 17 August. [Online]. Available WWW: www.engineeringnews.co.za/article.php?a_id=113652.

Ezekwesili, O. 2008. Speech at the Chinese Center for Economic Research of Peking University, Beijing, China. 6 March.

Mangena, M. 2008 Budget Vote debate 2008/2009, National Assembly, May. Cape Town.

Rabson, M. 2006. Is South Africa on the competitiveness world map? Computer Business Review (September).

World Competitiveness Scoreboard, 2008. IMD. [Online]. Available WWW:, www.imd.ch. (Accessed 9 June 2008).

World Economic Forum, 2008: Interviews with Aliko Dangote, President and Chief Executive Officer, Dangote Group, Nigeria; Co-Chair, World Economic Forum on Africa; E. Neville Isdell, Chairman and Chief Executive Officer, The Coca-Cola Company, USA; CoChair, World Economic Forum on Africa and Wendy Luhabe. 5 June. Cape Town.

\footnotetext{
About the author

Marié-Luce Muller is a consulting CI analyst with IBIS Business and Information Services (Pty) Ltd, a leading Pretoria-based CI consultancy. She has a distinguished career in CI. Her primary experience lies in assisting companies in honing their CI capabilities. She also performs tracking and scanning activities on behalf of companies. Marié-Luce has published many articles on competitive intelligence (CEO Magazine, Finance Week, Business Week, Beeld, Die Burger and the South African Journal of Business Management), including an article on South Africa as an emerging CI player, which was published in an international publication of the Society of Competitive Intelligence Professionals (SCIP). She has also published a series of booklets on CI (Nuts and Bolts business series, published by Knowledge Resources) and is a member of a research team participating in an international study of CI practices among exporting companies. Previously, she was involved in research into the status of CI practices in South Africa. A member of SCIP, she holds a postgraduate degree from the University of Stellenbosch.
} 
SSN 1560-683X

Published by InterWord Communications for Department of Information and Knowledge Management, University of Johannesburg 